\title{
EFFECT OF GAMMA RAYS ON PROLAMIN AND PROLAMIN LIKE PROTEIN ACCUMULATION, GROWTH AND CYTOLOGY OF BAJRA (PENNISETUM GLAUCUM L. R.BR.)
}

\section{VIVEK SINGH}

Department Of Botany, Shri Jai Narain Pg College, Lucknow, UP, India

\begin{abstract}
The present paper seeks to investigate the effect of gamma irradiation on the protein quality of Pennisetum grains and Nitrogen accumulation capacity (in terms of total accumulated protein in seeds) of the plants. Irradiated and control seeds were sown with three different Nitrogen supplies for each irradiated set. Each set was sown in three replicates. Protein composition and total protein content were evaluated along with cytological analysis for chromosomal stability. The results indicated that at low doses, gamma irradiation caused no effect on Nitrogen accumulation in seeds i.e. total protein content and protein fractions. However, at higher doses, the protein fractions of prolamin and glutelin showed increase. There was also a definite increase in total accumulated Nitrogen in the form of total protein content in the seeds. Keywords: Glutelin, Pennisetum, Prolamin, Protein content.
\end{abstract}

Received: Apr 01, 2021; Accepted: Apr 30, 2021; Published: May 08, 2021; Paper Id.: IJBRJUN20218

\section{INTRODUCTION}

Pearl millet (Pennisetum glaucum (L.) R. Br. Emend Stuntz syn. Pennisetum typhoides (Burm). Stapf and Hubbard, $2 \mathrm{n}=14$ ) or bajra (in Hindi) is an important crop of rainfed areas of semi-arid tropics. In India, it covers around 7.12 million ha of marginal and sub-marginal lands primarily of Rajasthan, Gujarat, Haryana, Uttar Pradesh and Maharashtra producing around $8.06 \mathrm{~m}$ tons with a productivity of around 1132 kilogram/hectare (ICAR, Pearl Millet News, April 2017). This is over $30 \%$ of the world acreage and $11 \%$ of total cereal production in India. The rainfall over this area ranges from $200 \mathrm{~mm}$ to $1200 \mathrm{~mm}$, received during June end to September. Therefore, pearl millet faces moisture-stress during its growing period due to low and ill-distributed rainfall. Still among millets, it is second only to Sorghum in the area and production (krishikosh.egranth.ac.in).

In the drier parts of the country, this crop provides a healthy diet for the underprivileged population who cultivate it using primitive techniques and minimum inputs under scarcity of irrigation. The grains are rich source of carbohydrates and are crushed to flour, which is used for making bread (chapattis) or cooked in water till it becomes a paste of suitable consistency (sangati, hittu or mudde). The seeds of Bajra contain 2.5-3.5\% mineral content and $4.0-8.0 \%$ fats. Because of high fat, it is also used for making a creamy dessert (Rabari) in Punjab area of India. According to the agency Nutritive Value of Indian Foods (NIN), the average carbohydrates present in $100 \mathrm{~g}$ of Bajra seeds is $67.5 \mathrm{~g}$. This value is less than that of Triticum, Oryza and Sorghum. The average protein present in $100 \mathrm{~g}$ of Pennisetum is $11.6 \mathrm{~g}$ as compared to Triticum being $11.8 \mathrm{~g}$, Oryza being $6.8 \mathrm{~g}$, Zea $4.7 \mathrm{~g}$ and Sorghum being 10.4g (NIN, 2003). This makes Pennisetum, a low carbohydrate and high protein food.

Among amino acids, Pearl millet is up to $40 \%$ richer in methionine content as compared to other grains and millets. "The lysine content of pearl millet is $21 \%$ higher than corn and 36\% higher than Sorghum" (Irén Léder, 2004). In view of its higher nutritional contents, Pennisetum is being considered as one of the most important dietary supplements. 
According to Osborne (1924), the crude proteins present in various grains can be broadly divided into of four types on the basis of their solubility.

\begin{tabular}{|c|c|l|}
\hline S.No. & Name of Protein Fraction & Solubility in \\
\hline 1 & ALBUMIN & Water \\
\hline 2 & GLOBULIN & Saline solution \\
\hline 3 & PROLAMIN & Alcohols \\
\hline 4 & GLUTELIN & Alkali \\
\hline
\end{tabular}

These four are present in almost all known plant storage proteins, but their amounts show great variations in different plants. In the present study, we would focus on the Prolamin fraction which is alcohol soluble and made up of large amounts of Proline and Glutamine amino acids. "Prolamin is the main contributors of protein body deposition in the endosperm of all cereal grains except oats and rice" (Shewry \& Casey 1999). Millets are typically rich in proteins as compared to cereals. On an average, they contain 22-35\% Prolamin, 28-32\% Glutelin and 22-28\% Albumins. This also includes proteins similar in structure to the above-mentioned ones.

"Pearl millet is gluten free grain and is the only grain that retains its alkaline properties after being cooked which is ideal for people with wheat allergy" (Irén Léder, 2004). The high levels of prolamins make the starch in the endosperm less available in the diet. This is because of the property of prolamins to form a tough layer around starch grains which is removed only after fermentation. This property will be very useful to those who want to cut down on their carbohydrate intake.

In spite of its great importance as a crop, Pearl millet has received limited attention so far as studies on its biochemistry, cytogenetics and biology are concerned (Rai et al. 2012). The exact mechanism of protein formation in Pennisetum including genes responsible and effect of different agents on the process are still unknown. The study of these aspects might bring out much important information that can be helpful in improvement of selected traits in this crop plant. It has been observed by many workers that gamma irradiation has significant effect on storage proteins of different cereals. It is therefore imperative that similar results would be obtained in millets also. But any such study is either lacking or very obscure in Millets particularly in case of Pearl Millet. If by mutagenesis, a cultivar of higher prolamin content could be developed it would help in improving the agronomic importance of this crop. The present study deals with this aspect in correlation with growth and cytology of Pearl Millet.

\section{MATERIALS AND METHODS}

Bajra (Pennisetum glaucum) local cultivar Mainpuri was used in this study. Grain samples were obtained from the CSA Agricultural University, Kanpur. Samples were cleaned and placed in polyethylene bags under room temperature. The seeds were irradiated with gamma rays at National Botanical Research Institute, Lucknow using 0.10, 0.25, 0.50 and 1.0 KGys gamma streams using an experimental Cobalt-60 gamma source.

The irradiated seeds were germinated in petridishes using wet cotton wool along with the control seeds to record germination percentage. Some of the seeds were fixed in Carnoy's Fluid to study mitosis in root tips as an effect of gamma irradiation. Other seeds were sown in randomized block design with three replicates per dose of gamma rays along with suitable rows of controls to grow the crop. Survival of the seeds was recorded and periodic measurement of growth was done. Finally, at the time of flowering and cob formation, some flowers from each cob were fixed in Carnoy's fluid to 
study meiosis in treated plants. Further, after harvesting the seeds of each set, they were collected in bulk for each dose of gamma rays and nitrogen supply variation. They were kept under controlled moisture conditions at room temperature.

Mitosis and meiosis were studied using standard acetocarmine squash method. The total protein extraction was done using the method of Basha et al., (1976), modified by Rajaram and Janardhanan, (1990). Estimation was done by the method of Lowry et.al. (1951). Each sample was analyzed in triplicate and the values were then averaged.

\section{RESULTS AND DISCUSSION}

In Pennisetum, Prolamin and similar proteins form the major chunk of total protein fraction (Okoh et al. 1985) ie. 33.149.5\%. These are sometimes referred to as Pennisetins. Glutelin and related proteins also have high amount ranging from 33.1-49.5\%. Globulins and Albumins share 11.6-16.8\% and 6.4-9.6\% respectively. The effect of gamma irradiation on protein fractions of Pennisetum is shown in Table 1. At lower doses of radiation, no significant differences were observed in any fraction. However, at highest dose, prolamin and glutelin fractions showed an increase and so did the total protein.

Table 1: Effect of Gamma Irradiation on Total Proteins and Protein Fractions

\begin{tabular}{|c|c|c|c|c|c|}
\hline $\begin{array}{c}\text { Dose of gamma } \\
\text { Ray Exposure } \\
\text { KGys }\end{array}$ & $\begin{array}{c}\text { Total } \\
\text { Protein } \\
\text { content } \%\end{array}$ & Albumins $\%$ & Globulins\% & Prolamins \% & Glutelin\% \\
\hline Control & 10.1 & 8.1 & 14.2 & 39.2 & 38.5 \\
\hline 0.10 KGy & 10.6 & 7.5 & 14.6 & 40.1 & 37.8 \\
\hline 0.25 KGy & 11.7 & 6.9 & 13.6 & 39.9 & 39.6 \\
\hline 0.50 KGy & 11.9 & 7.1 & 12.6 & 40.6 & 39.7 \\
\hline 1.00 KGy & 15.5 & 7.5 & 8.1 & 44.3 & 40.1 \\
\hline
\end{tabular}

It was clearly seen that the treated sets at low doses had no or very insignificant effect on the total protein content as well as relative protein fractions of the seeds. However, at the highest dose ie $1.0 \mathrm{KGys}$ a considerable increase in the total protein content was observed. There was also a slight increase in the prolamin and glutelin contents at the cost of the albumin and globulin fractions (Table 1 \& Fig 1). This can be attributed to the fact that high gamma ray dose might have activated certain genes related to the uptake of nitrogen and its final accumulation in the seeds in the form of proteins. An intricate interplay of genes and environment can be suspected here but further investigations are definitely needed.

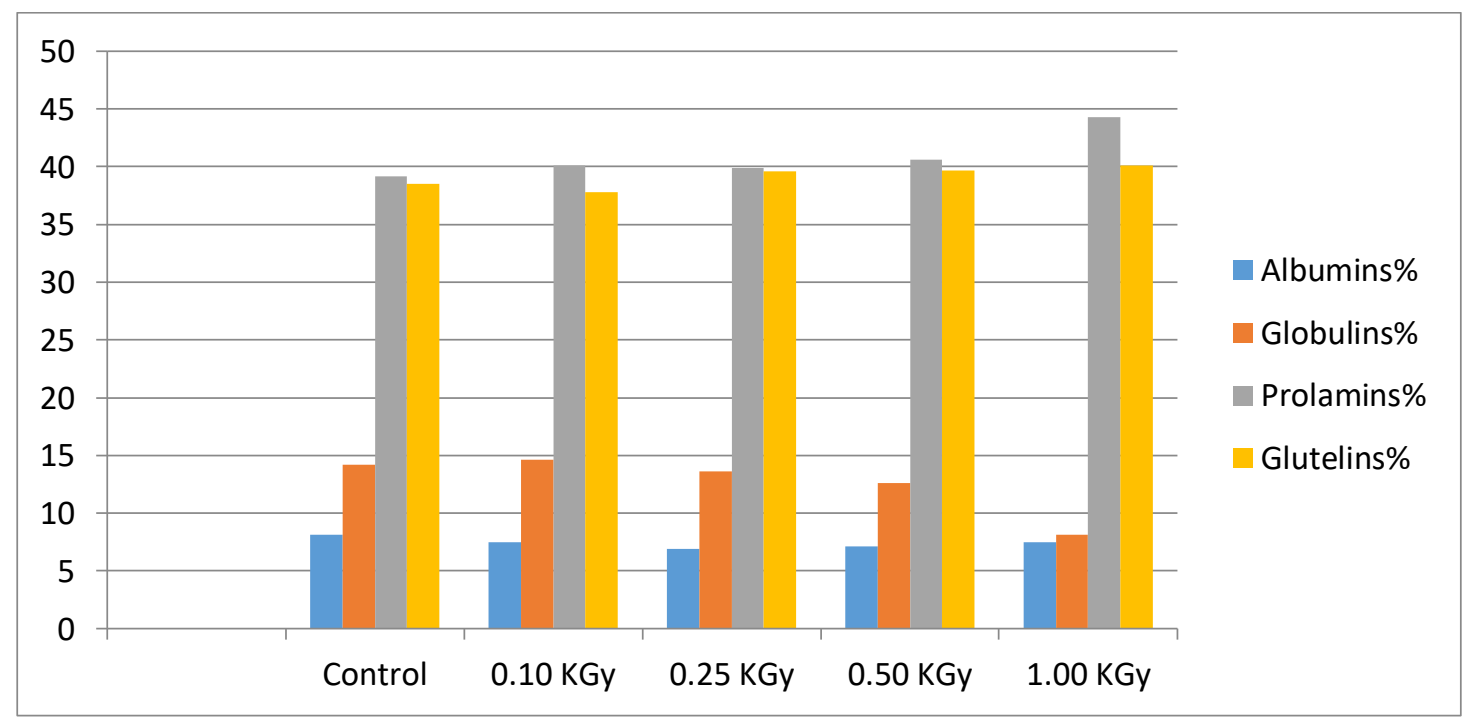

Figure 1: Average Protein Composition in Each Treatment Set 
Cytologically, there were chromosomal aberrations in all the treated sets, but the amount of aberrations increased massively at 1.0 KGys dose. The pollen fertility lowered and micronuclei increased in number. This could be correlated with the lowering in the grain yield which decreased significantly even at the highest dose of treatment (Table 2). The main impact of gamma activation of genes seems to be increased in Nitrogen uptake. Higher $\mathrm{N}$ would mean higher protein content and since Prolamin are the biggest shareholders of this protein, their amount increases. This is also important since prolamin is essential for anabolic activities related to structure and components.

With low lysine and low sulphur content, Prolamin show high proline and glutamine fractions. These are rich in $\mathrm{N}$ and thus help in increasing the total $\mathrm{N}$ content of the grain. Gamma irradiation brings about an increase in the total protein and in turn the Prolamin content. However, a reduction in fat and carbohydrate brings about a reduction in the overall yield. Thus, a negative correlation can be seen between total protein value of grain and the yield. This is probably the reason why the farmers do not accept high protein cultivars of millets since yield is the most important factor in agriculture.

\section{CONCLUSIONS}

The main conclusions that can be drawn from the study are as follows: - Gamma irradiation has the potential to induce increase in the total protein content and the Prolamin fraction of the protein in Pearl millet. However, this increase is invariably associated with a reduction in the yield or total production. The reason for this appears to be a reduction in the carbohydrate and fat fraction at the cost of protein, but the explanation needs experimental backing. It can also be inferred here that the genetic control of protein accumulation is very complex, thus, limiting our ability to increase it much. The available literature shows that there is a low genetic variation in Pearl millet and genes responsible for protein accumulation are still unidentified. Further researches for identification of genes might help in greater improvement of protein content in this crop. The results of present study broadly corroborate with the previous studies and can be helpful in deciding the dosage for breeding programs.

Table 2: Effect of Gamma Irradiation on Cytological Aberrations

\begin{tabular}{|c|c|c|c|c|c|c|c|c|c|c|c|c|c|c|c|c|c|c|c|c|c|c|c|}
\hline \multirow{2}{*}{$\begin{array}{c}\text { Dose of } \\
\text { Gamma } \\
\text { Ray } \\
\text { Exposure } \\
\text { KGys }\end{array}$} & \multirow{2}{*}{$\begin{array}{c}\mathrm{CF} / \mathrm{bi} \\
\quad \mathbf{y} \\
\pm \mathrm{SE}\end{array}$} & \multicolumn{8}{|c|}{$\begin{array}{l}\text { Metaphase III Abnormalities } \\
(\% 6)\end{array}$} & \multicolumn{6}{|c|}{ Anaphase III Abuormalities ( $\%$ ) } & \multicolumn{3}{|c|}{$\begin{array}{c}\text { Telophase III abu } \\
(\%)\end{array}$} & \multicolumn{2}{|c|}{$\begin{array}{l}\text { Cytoki-nesis } \\
\text { abn }(\%, 6)\end{array}$} & \multicolumn{2}{|c|}{$\begin{array}{l}\text { Other } \\
\text { abn } \\
(0 / 6)\end{array}$} & \multirow{2}{*}{$\begin{array}{l}\text { T. Ab } \\
(\%, 6)\end{array}$} \\
\hline & & Sc & $\mathrm{Pc}$ & Do & Nv & $\mathrm{Ur}$ & $\mathrm{Fg}$ & St & $\mathrm{Sa}$ & $\mathrm{Lg}$ & $\mathrm{Br}$ & Us & Ns & St & $\mathrm{A \varphi}$ & $\mathrm{Lg}$ & $\mathrm{Br}$ & $\mathrm{M} n$ & $\operatorname{Tr}$ & $\mathrm{Pa}$ & c & Sh & \\
\hline Control & $\begin{array}{l}1.74+ \\
0.02\end{array}$ & 0.13 & & 0.20 & & & & & & & & & & 0.07 & & & & & & & & & 0.40 \\
\hline $0.10 \mathrm{KG}$ & $\begin{array}{c}1.78+ \\
0.21\end{array}$ & 1.08 & 2.15 & 1.48 & & & & 0.81 & 1.21 & 0.67 & & & 0.87 & 0.74 & & 0.47 & & 0.40 & & & & & 9.89 \\
\hline $0.25 \mathrm{KG}$ & $\begin{array}{c}1.76+ \\
0.11\end{array}$ & 1.29 & 259 & 1.76 & 1.09 & 0.68 & & 1.43 & 1.36 & 1.22 & 0.48 & 0.41 & 1.02 & 0.95 & & 1.16 & & 0.61 & & & & & 16.05 \\
\hline $0.50 \mathrm{KG}$ & $\begin{array}{c}1.48+ \\
031 \\
\end{array}$ & 1.48 & 1.34 & 0.81 & 1.21 & 0.54 & 1.07 & 1.41 & 1.21 & 0.87 & 1.61 & 0.81 & 0.60 & 1.34 & 1.01 & 0.81 & 0.67 & 0.60 & 0.13 & 054 & 0.27 & 0.47 & 18.82 \\
\hline $100 \mathrm{KG}$ & $\begin{array}{c}1.26+ \\
0.09\end{array}$ & 2.43 & 2.16 & 1.01 & 1.69 & 0.88 & 2.29 & 1.35 & 0.81 & 1.62 & 1.75 & 1.21 & 1.08 & 1.48 & 1.21 & 0.81 & 0.67 & 0.74 & & 0.61 & 1.15 & & 24.29 \\
\hline
\end{tabular}

CF/biv=Chisama Frequency/bivalent: Sc=Scattering of chromosomes: Pc=Precocious movement of chromosomes; $\mathrm{Do}=$ Disturbed orientation of chromosomes; $\mathrm{Mv}=$ Multivalent formation; $\mathrm{Uv}=$ Univalent formation; $\mathrm{Fg}=\mathrm{Fragmentation}$ of chromosomes; $\mathrm{St}=$ Stickiness of chromosomes; $\mathrm{Sa}=$ Secondary association of bivalents; Lg=Lagging chromosomes; Br=Bridge 
formation between poles; Us=Unequal separation of chromosomes at anaphase; Ns=Non synchronous disjunction; Mp=Multipolarity; Mn=Micronuclei; Tr=Triads; Pa=Polyads; $\mathrm{Cy}=$ Cytomixis; Sh=Shrinking of PMCs.

\section{REFERENCES}

1. Alsmadi, Zeinab Y., and Mohamed Bourham. "SHIELDING PROPERTIES OF ALLOY 709 ADVANCED AUSTENITIC STAINLESS STEEL AS CANDIDATE CANISTER MATERIAL IN SPENT FUEL DRY CASKS." International Journal of Physics and Research 10.2 (2020): 11-26.

2. Basha, S. M. M., Cherry, J. P., Young, C. T. (1976). Changes in free amino acids, Carbohydrates and proteins of maturity seeds from various peas (Arachis hypogaea) cultivars. Cereal Chem., 53: 583597.

3. Chandna, M. and Matta K. N., (1990). Characteristics of pearl millet protein fractions. J. Biol. Chem., 29: 3395-3399.

4. http://krishikosh.egranth.ac.in/handle/1/5810057489

5. ICAR Pearl Millet News, (April, 2017). All India Coordinated Research Project on Pearl Millet, Jodhpur. PI

6. Irén Léder (2004). Sorghum and Millets, in Cultivated Plants, Primarily as Food Sources, [Ed. György Füleky], in Encyclopedia of Life Support Systems (EOLSS), 2004, Developed under the Auspices of the UNESCO, EOLSS Publishers, Oxford, U.K.

7. Jain, Dinesh Kumar, and Raj Kumar Nagar. "Induced Variability by Gamma Irradiation in Isabgol (Plantago Ovata Forsk)." International Journal of Agricultural Science and Research (IJASR) 8.4 (2018): 73-78.

8. Karishma, Lvar. "Genomic Damage Induced by Individual and Combination Treatment Of Gamma Rays and Ethyl Methane Sulphonate in Coriandrum Sativum." International Journal of Botany and Research (IJBR) 3. 2, Jun 2013, 7985.

9. Lowry O. H., Rosebrough N. J., Farr A. L., Randall R. J. (1951). Protein measurement with the Folin phenol reagent. J Biol Chem., 193(1): 265-75.

10. NIN., Nutritive value of Indian Foods, Ed Gopalan and Deosthale, National Institute of Nutrition, Hyderabad, 2003

11. Okoh, P. N., Nwasike, C. C., Ikediobi, C. O. (1985). Studies on seed protein of pearl millets. 1. Amino acid composition of protein fractions of early and late maturing varieties. J. Agric. Food Chem. 33 (1), 55-57.

12. Osborne, T. B. (1924). The Vegetable Proteins, Published Longmans, Green and Co., London. Pp. 34-35

13. RASHID, MA, et al. "STUDY ON THE EFFECT OF CHITOSAN IN POLY (VINYL PYRROLIDONE) HYDOGEL PREPARED BY THE APPLICATION OF GAMMA RADIATION." Technology (JPPT) 1.1 (2015): 65-70.

14. Rai K. N., Yadav O. P., Gupta, S. K., Mahela R. S. (2012). Emerging research priorities in pearl millet. Journal of SAT Agricultural Research, 10, 56-60.

15. Rajaram, N., Janardhanan, K. (1990). Chemical composition and Nutritional evaluation of certain under-explored Vigna sp. Food Sci. Nutri., 42: 213-221.

16. SAIED, BASHAIR M., TAGHREED A. YOUNIS, and HUSSEIN A. JAN MIRAN. "GAMMA RAY PROPERTIES FROM 70 AS NUCLEUS." International Journal of Physics and Research (IJPR) 4.2, Apr 2014, 15-26

17. SAIKIA, TARUN, and RUPJYOTI STAFFORD. "Rice Cultivars (Oryza sativa L) Susceptible to Iron Toxicity have poor Grain Nutritional Quality." Inter. J. Agri. Sci. and Resea 7 (2017): 453-464.

18. Shewry P. R., Casey R. (1999). Seed Proteins. Kluwer Academic Publishers, Dordrecht, The Netherlands, pp 884. 
19. Shewry P. R., Halford N. G. (2002). Cereal seed storage proteins: structures, properties and role in grain utilization. J. Exp. Bot., 53: 947-58. 